\section{Response to: 'Standard dose of ustekinumab for childhood-onset deficiency of interleukin-36 receptor antagonist' by Cherqaoui et al}

The case reported by Cherqaoui et al ${ }^{1}$ on ustekinumab in the treatment of deficiency of interleukin-36 receptor antagonist (DITRA) is interesting in several aspects.

The authors describe intrathecal elevation of proinflammatory cytokines, which is a novel and intriguing finding. The mutation in their case is identical to that of the Dutch/Moroccan patient we described. The total absence of any clinical disease activity in a genetically affected younger sister of the patient further supports the variable expression of identical IL36RN mutations as reported by Cherqaoui et al.

As observed in our cases, the patient was treated with several drugs with an absent or only transient improvement. ${ }^{2}$ At variance with our previous experience, the use of ustekinumab at standard dose in monotherapy was able to completely control the clinical picture, without the need for any topical steroids. These observations underline the clinical spectrum of disease severity associated with DITRA. In our previous experience, both patients displayed an initial response at standard doses but displayed a tendency to mild/ moderate relapses in proximity to the scheduled doses. According to the few cases so far described, it is therefore conceivable that ustekinumab should be considered among the first-line treatments for this severe condition. As suggested by Cherqaoui et al, a standard dose of $0.75 \mathrm{mg} /$ kg every 12 weeks could be sufficient to completely control disease flares and should therefore be used as an initial approach. However, higher doses at more frequent intervals could be necessary to achieve a complete remission in patients with a partial clinical response, with a good safety profile.
Nadia Bonekamp, ${ }^{1}$ Roberta Caorsi, ${ }^{2}$ Joost Frenkel, ${ }^{1}$ Marco Gattorno ${ }^{2}$

${ }^{1}$ Department of Pediatrics, Wilhelmina Children's Hospital, University Medical Center Utrecht, Utrecht, The Netherlands

${ }^{2}$ Rheumatology Unit, G Gaslini Institute, Genova, Italy

Correspondence to Dr Marco Gattorno, Clinica Pediatrica e Reumatologia, G. Gaslini Institute, Genova, Italy; marcogattorno@gaslini.org

Handling editor Josef S Smolen

Contributors All the authors wrote the reply letter.

Competing interests None declared.

Patient consent Obtained.

Ethics approval G Gaslini Institute.

Provenance and peer review Commissioned; internally peer reviewed.

(c) Article author(s) (or their employer(s) unless otherwise stated in the text of the article) 2018. All rights reserved. No commercial use is permitted unless otherwise expressly granted.

\section{Check for updates}

To cite Bonekamp N, Caorsi R, Frenkel J, et al. Ann Rheum Dis 2018;77:e89.

Received 20 December 2017

Accepted 23 December 2017

Published Online First 13 January 2018

\section{G Linked}

- http://dx.doi.org/10.1136/annrheumdis-2017-212793

Ann Rheum Dis 2018;77:e89. doi:10.1136/annrheumdis-2017-212832

\section{REFERENCES}

1 Cherqaoui B, Rossi-Semerano L, Piram M, et al. Standard dose of Ustekinumab for childhood-onset deficiency of interleukin-36 receptor antagonist. Ann Rheum Dis 2018;77:e88.

2 Bonekamp N, Caorsi R, Viglizzo GM, et al. High-dose ustekinumab for severe childhood deficiency of interleukin-36 receptor antagonist (DITRA). Ann Rheum Dis 2017;77:1241-3. 